\section{見えたこと， 伝えたいこと．}

巻 /頭 / 言
昨年は生物物理にとって 50 周年という節目の年でした。では, 私にとってはどんな年だったのかと考光ると，今の自分の研究に 手をつけてから 20 年近くが過ぎたことになります。そのはじめ のころの実験を考えると，よくうまくいったものだと思うことも しばしばです。生物物理の分野は理論系・実験系に分けると圧倒 的に実験系が多い，実験系の場合，新しく系を組むときには何か ら始めるのでしょらか？ 先人の意見を聞く，真似る，掘り起こ すなぞがありますが，いずれにしても個人ではじめて手をつける ときには，いろいろと苦労があるものです，その一方で，そのと きの苦労はこれからの自分の研究にとって，財産になるでしょ ら.

私も生物物理学会に長く所属していますが，はじめは生命の起 源，次に生体膜，今は蛍光測定を扣もに研究を行っています。 あ まりにも分野が異なるので，何だコリャと思う方もいるかもしれ ませんが，その代りはじめての経験としていろいろと印象に残る ことも多くあります。その中から1つ紹介しましょう。

今の蛍光相関装置を構築し始めた頃, レーザーの光を絞って, そこに出入りをする蛍光色素の動きを PMTやCCD カメラで測 定をしていると，カメラ画像の絞った小さな光の領域でさらに小 さな光の点が動いているのが見えました．いろいろ焦点を変えて みると，かなり限定された範囲で，カバーガラスの境界付近であ ることがわかります。その当時は多分ゴミかなんかを見たのだと 納得していましたが，薄々は，蛍光色素 1 分子を見たのかと，心 に残っていました。しかし，それ以上の測定も解析も行っていま せん，今から考光机ば，カバーグラス付近で分子の動きが遅く なったこと，また，カバーグラスがピンホールの役目をして， バックグラウンドを下げていたことなどで，説明がつくのだと思 います。しかし，あのころ，暗い視野の中の緑の光の中で肉眼で も確認した蛍光色素の動きは強く印象に残っています。観察しな がら，見えるはずはない，でも見えているのは何か？と自問しな がらも，周りに声を掛けて見せまわった記憶があります。

そのような小さな発見や感動をどのように伝えていくのか，数 式やグラフだけではない個人の経験や感動を次に伝えていくこと が生物物理の裾野を広げるために重要だと思っています。

新しい季節が巡り，新しいこと，困難なことが続いている会員 もいると思います。その経験をぞうか伝えてみてください，

金城政孝, Masataka KINJO

北海道大学，教授 